\title{
OPEN Author Correction: Characterization of Retinal Ganglion Cell and Optic Nerve Phenotypes Caused by Sustained Intracranial Pressure Elevation in Mice
}

\author{
Guofu Shen ${ }^{1}$, Schuyler Link ${ }^{1}$, Sandeep Kumar ${ }^{1}$, Derek M. Nusbaum ${ }^{1,2}$, DennisY. Tse $\mathbb{C}^{1,3}$, \\ Yingbin Fu' ${ }^{1,2}$, Samuel M. Wu ${ }^{1,2}$ \& Benjamin J. Frankfort ${ }^{1,2}$
}

Correction to: Scientific Reports https://doi.org/10.1038/s41598-018-21254-8, published online 12 February 2018

The Acknowledgements section in this Article is incomplete.

“This research was supported by the NIH (R01 EY025601 to B.J.F., R01 EY019908 to S.M.W., R01 EY022901 to Y.F., and P30 EY002520 to S.M.W.), with additional funding from Research to Prevent Blindness (Baylor College of Medicine), the Retina Research Foundation (S.M.W. and B.J.F.) and Hong Kong Polytechnic University grant \# G-UA7J (D.Y.T.). We thank Dr. Yong Park for critically reading the manuscript.”

should read:

“This research was supported by the NIH (R01 EY025601 to B.J.F., R01 EY019908 to S.M.W., and P30 EY002520 to S.M.W.), with additional funding from Research to Prevent Blindness (Baylor College of Medicine), the Retina Research Foundation (S.M.W. and B.J.F.) and Hong Kong Polytechnic University grant \# G-UA7J (D.Y.T.). We thank Dr. Yong Park for critically reading the manuscript."

(i) Open Access This article is licensed under a Creative Commons Attribution 4.0 International Cicense, which permits use, sharing, adaptation, distribution and reproduction in any medium or format, as long as you give appropriate credit to the original author(s) and the source, provide a link to the Creative Commons license, and indicate if changes were made. The images or other third party material in this article are included in the article's Creative Commons license, unless indicated otherwise in a credit line to the material. If material is not included in the article's Creative Commons license and your intended use is not permitted by statutory regulation or exceeds the permitted use, you will need to obtain permission directly from the copyright holder. To view a copy of this license, visit http://creativecommons.org/licenses/by/4.0/.

(C) The Author(s) 2019

\footnotetext{
${ }^{1}$ Department of Ophthalmology, Baylor College of Medicine, Houston, TX, USA. 2Department of Neuroscience, Baylor College of Medicine, Houston, TX, USA. ${ }^{3}$ School of Optometry, The Hong Kong Polytechnic University, Hong Kong, Hong Kong. Correspondence and requests for materials should be addressed to B.J.F. (email: benjamin. frankfort@bcm.edu)
} 